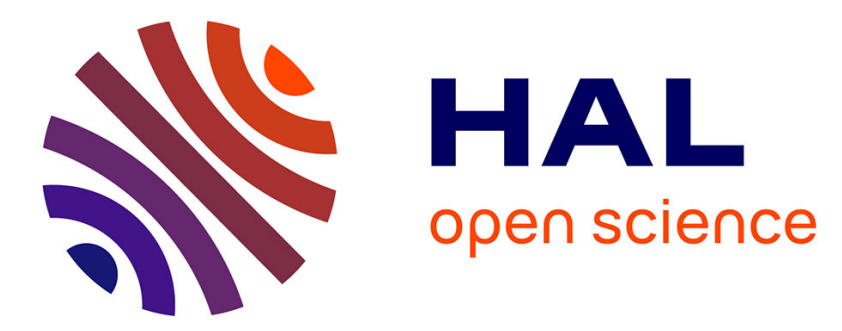

\title{
Improvement of skin wound healing in diabetic mice by kinin $\mathrm{B} 2$ receptor blockade
}

D. Desposito, C. Chollet, C. Taveau, V. Descamps, F. Alhenc-Gelas, R. Roussel, Nadine Bouby, L. Waeckel

\section{- To cite this version:}

D. Desposito, C. Chollet, C. Taveau, V. Descamps, F. Alhenc-Gelas, et al.. Improvement of skin wound healing in diabetic mice by kinin B2 receptor blockade. Clinical Science, 2015, 130 (1), pp.4556. 10.1042/CS20150295 . hal-01288792

\section{HAL Id: hal-01288792 \\ https://hal.sorbonne-universite.fr/hal-01288792}

Submitted on 15 Mar 2016

HAL is a multi-disciplinary open access archive for the deposit and dissemination of scientific research documents, whether they are published or not. The documents may come from teaching and research institutions in France or abroad, or from public or private research centers.
L'archive ouverte pluridisciplinaire HAL, est destinée au dépôt et à la diffusion de documents scientifiques de niveau recherche, publiés ou non, émanant des établissements d'enseignement et de recherche français ou étrangers, des laboratoires publics ou privés. 


\section{Improvement of skin wound healing in diabetic mice by kinin $\mathrm{B} 2$ receptor blockade}

Dorinne Desposito ${ }^{1,2,3}$, Catherine Chollet ${ }^{1,2,3}$, Christopher Taveau ${ }^{1,2,3}$, Vincent Descamps $s^{4,5}$, François Alhenc-Gelas ${ }^{1,2,3}$, Ronan Roussel ${ }^{1,6,7}$, Nadine Bouby ${ }^{1,2,3}$, Ludovic Waeckel ${ }^{1,2,3}$

${ }^{1}$ INSERM U 1138, Cordeliers Research Center, Paris, France; ${ }^{2}$ Paris Descartes University, Paris, France; ${ }^{3}$ Pierre et Marie Curie University, Paris, France; ${ }^{4}$ INSERM U 976, Denis Diderot University, Paris, France; ${ }^{5}$ Dermatology Department, Bichat Hospital, AP-HP, Paris, France; ${ }^{6}$ Denis Diderot University, Paris, France;

${ }^{7}$ Diabetology, Endocrinology and Nutrition Department, DHU FIRE, Bichat Hospital, AP-HP, Paris, France

Laboratory address: INSERM U 1138, Centre de Recherches des Cordeliers, 15 rue de l'Ecole de Médecine, 75006 Paris, France

Keywords: Bradykinin receptors. Type 1 diabetes. Type 2 diabetes. Skin wound healing. Kallikrein-kinin system.

Short title: Kinins and cutaneous wound healing

Corresponding author:

Nadine Bouby Address: INSERM U 1138, Centre de Recherches des Cordeliers, 15 rue de l'Ecole de Médecine, 75006 PARIS, FRANCE

Tel: $33(0) 144278114$

Fax: $33(0) 144276421$

E-mail: nadine.bouby@crc.jussieu.fr 


\begin{abstract}
Impaired skin wound healing is a major medical problem in diabetic subjects. Kinins exert a number of vascular and other actions limiting organ damage in ischemia or diabetes but their role in skin injury is unknown. We investigated, through pharmacological manipulation of kinin $\mathrm{B} 1$ and $\mathrm{B} 2$ receptors $(\mathrm{B} 1 \mathrm{R} / \mathrm{B} 2 \mathrm{R})$, the role of kinins in wound healing in non-diabetic and diabetic mice.

Using two mouse models of diabetes (streptozotocin-induced and $\mathrm{db} / \mathrm{db}$ mice) and nondiabetic mice, we assessed effect of kinin receptor activation or inhibition by subtype selective pharmacological agonists (B1R and B2R) and antagonist (B2R) on healing of experimental skin wound. We also studied effects of agonists and antagonist on keratinocytes and fibroblasts in vitro.

B1 and B2 receptor mRNAs level increased one to two fold in healthy and wounded diabetic skin compared to non-diabetic skin. Diabetes delayed wound healing. B1R agonist had no effect on wound healing. In contrast, B2R agonist impaired wound repair in both nondiabetic and diabetic mice, inducing skin disorganization and epidermis thickening. In vitro, $\mathrm{B} 2 \mathrm{R}$ activation unbalanced fibroblast/keratinocyte proliferation and increased keratinocyte migration. These effects were abolished by co-administration of B2R antagonist. Interestingly, in the two mouse models of diabetes B2R antagonist administered alone normalized wound healing. This effect was associated with induction of MCP1/TNF $\alpha$ mRNAs.

Thus, stimulation of kinin B2 receptor impairs skin wound healing in mice. B2R activation occurs in the diabetic skin delays wound healing. B2R blockade improves skin wound healing in diabetic mice and is a potential therapeutic approach to diabetic ulcers.
\end{abstract}




\section{Abbreviations}

ACE: Angiotensin I-converting enzyme

AT1R: Angiotensin II type 1 receptor

AT2R: angiotensin II type 2 receptor

AU: arbitrary units

B1R: bradykinin type-1 receptor

B2R: bradykinin type-2 receptor

B1R-ag: bradykinin type-1 receptor agonist

B2R-ag: bradykinin type-2 receptor agonist

B2R-ant: bradykinin type-2 receptor antagonist

Diab: diabetic

DMEM: Dulbecco's Modified Eagle Medium

ERK1/2: p44/42 MAP-Kinase

FBS: Foetal Bovine Serum

IL-6: Interleukine 6

KKS: Kallikrein-Kinin(s) System

MCP-1: Monocyte Chemoattractant Protein-1

NBCS: New Born Calf Serum

NonDiab: non-diabetic

PBS: Phosphate Buffered Saline

SAP: Serum amyloid $P$

STZ: streptozotocin

STZ-Diab: diabetes induced by streptozotocin

TGF-beta: Transforming growth factor beta

TNF-alpha: Tumor Necrosis Factor alpha 


\section{Introduction}

Impaired skin wound healing is a source of morbidity, disability, loss of quality of life and mortality in subjects affected by diabetes. Foot ulcers affect at least once in their life about $15 \%$ of patients with diabetes. Amputation rate is high in affected patients[1-3]. The pathogenesis of chronic foot ulcers is multifactorial and still incompletely understood. Loss of insulin action, hyperglycaemia, ischemia secondary to micro- and macro-angiopathy, neuropathy and infection all contribute to delayed skin repair and favour tissue necrosis, increasing amputation risk[4]. Improving skin wound healing in patients with diabetes is an important therapeutic issue.

Skin healing after wounding involves several different biological processes and comprises an acute response phase with haemostasis and inflammation, a granulation phase with cell migration, angiogenesis, production of extracellular matrix, wound contraction and re-epithelisation and a late scar maturation phase. Various cell types are involved in these processes: platelets, inflammatory cells, endothelial cells, fibroblasts and keratinocytes[5]. In diabetes, all phases of wound healing are altered. Cellular infiltration, migration and proliferation, and granulation tissue formation are delayed, together with impaired collagen organization and reduced angiogenesis[5]. Moreover, chronic hyperglycaemia alters fibroblasts and keratinocytes phenotypes. While impairment of the different components of the healing process has been documented in diabetes, therapeutic options for improving wound healing in diabetic subjects remain currently limited.

The kallikrein-kinin system (KKS) is implicated in physiological vasodilatation[6,7], anticoagulation[8], inflammation[9], and angiogenesis[10]. Previous studies have documented the role of this system in limiting organ damage in the setting of hemodynamic, hyperglycaemic or ischemic aggression[7,11]. We hypothesized that KKS could play a role in cutaneous responses to injury, especially in diabetes. Indeed, kinins have several cellular targets involved in skin repair including platelets, endothelial cells, keratinocytes and fibroblasts. Studies have documented the presence of the different components of the KKS in healthy, traumatized or diseased human skin[12-16]. Kinin receptors, bradykinin type-1 receptor (B1R) and bradykinin type-2 receptor (B2R), have been shown to participate in hyperproliferative process in chronic skin inflammation model[17]. Kinins increase skin microvascular blood flow in rabbits and humans[18]. These studies suggest a role for KKS in skin physiology. However, involvement of KKS in skin repair in the setting of diabetes remains undocumented.

The aim of the present study was to investigate the role of kinins and their receptors in wound healing in diabetic mice, and to compare with non-diabetic animals. Effect of potent selective pharmacological B1R or B2R agonists and/or of B2R antagonist was studied in vivo in mice and in vitro in cultured fibroblasts and keratinocytes. The study shows that a) B2R stimulation has deleterious effects in the wounded skin, unbalancing fibroblast/keratinocyte proliferation and migration and delaying cicatrisation; b) B2R activation occurs in the diabetic skin and impairs wound healing; c) B2R blockade improves wound healing in diabetic mice. 


\section{Materials and methods}

\section{Animals, experimental protocols and treatments}

Effects of B1R or B2R agonists or B2R antagonist on wound healing were studied, in both non-diabetic (NonDiab) and diabetic (Diab) mice. All mice were housed with a $12 \mathrm{~h}$ light/dark cycle and had free access to standard mice chow and water. All experimental procedures were approved by the local Ethics Committee for Animal Experiment Charles Darwin and performed in accordance with European legislation for the care and use of laboratory animals (L 358-86/609/EEC).

Murine model of type 1 diabetes Diabetes was induced in 10 weeks-old mice (C57BL/6J strain, male, Charles River Laboratories, France) by 5 daily i.p. injections of streptozotocin (STZ) (Sigma-Aldrich, France) $\left(50 \mathrm{mg} / \mathrm{kg}\right.$ body weight in $0.05 \mathrm{~mol} / \mathrm{L}^{-1}$ sodium citrate, $\mathrm{pH}$ 4.5)[10,19]. Diabetes was confirmed by assessing fasting blood glucose level at 0,7 and 30 days post STZ injection. After 5 weeks of confirmed diabetes (fasting blood glucose $>300$ $\mathrm{mg} / \mathrm{dl}$ ), excisional wounds were created on the back of the mice as described below. Control NonDiab animals were treated with vehicle only.

Murine model of type 2 diabetes Diabetic $\mathrm{db} / \mathrm{db}$ mice were obtained from Janvier Labs (Saint-Berthevin, France). Experiments were performed on male mice, 12 week-old. Only mice with 4 weeks of fasting blood glucose $>300 \mathrm{mg} / \mathrm{dl}$ were used.

Murine model of skin wound healing Animals were anesthetized by isoflurane inhalation $\left(1.5 \%\right.$ in $\left.\mathrm{O}_{2}\right)$. A dorsal $8 \mathrm{~mm}$ diameter full-thickness wound was made on dorsal depilated and cleaned (povidone-iodine solution) skin using a sterile biopsy punch (Kai medical, Japan)[20,21]. Buprenorphine (0.05 mg/kg; Buprécare, Axience, France) was administered as analgesic agent ten minutes prior and 24 hours after biopsy. Wounds were harvested by taking high-resolution photos every 2-3 days and the area was quantified relative to a millimetre reference using Image Analyzer Software (ImageJ, NIH) and expressed as percentage of wound area measured at day 0 . At day 11 after injury, corresponding to wound closure of NonDiab mice, animals were sacrificed by pentobarbital overdose $(120 \mathrm{mg} / \mathrm{kg})$ and a skin sample including wound and surrounding tissues was collected. One half of the sample was immediately fixed in $10 \%$ formalin for histological analysis, the other part being kept at $80^{\circ} \mathrm{C}$ for molecular analyses.

Treatments administration Immediately after wounding, mice were implanted i.p. with osmotic minipumps (Alzet, model 1002, Charles River, France) delivering the selective B1R agonist (SarLys[Hyp3,Ig15,DPhe8]desArg9-bradykinin, B1R-ag) or the selective B2R agonist ([Hyp(3),Thi(5),(N)Chg(7),Thi(8)]-bradykinin, B2R-ag)[22,23], both at non-hypotensive dose of $720 \mathrm{nmol} / \mathrm{kg}$.day ${ }^{-1}$ (B1R-ag: $796 \mu \mathrm{g} / \mathrm{kg}$ day $^{-1}$; B2R-ag: $813 \mu \mathrm{g} / \mathrm{kg}_{\text {.day }}{ }^{-1}$ ) [10], associated or not with the specific B2R antagonist (HOE140, Icatibant, B2R-ant)[24] at a dose of 380 $\mathrm{nmol} / \mathrm{kg}$ day $^{-1}\left(500 \mu \mathrm{g} / \mathrm{kg}^{\left.-d_{a y}{ }^{-1}\right)}\right.$ [25]. B2R-ant was also administered alone at the same dosage. Control mice received only vehicle (Phosphate Buffered Saline, PBS). Treatments were pursued until sacrifice ( $\mathrm{n}=7-30$ /group).

Histological analysis Skin biopsies fixed in 10\% formalin and embedded in paraffin were cut into 7- $\mu \mathrm{m}$ section and stained with Masson's trichrome according to the manufacturer's instructions (Sigma-Aldrich, France). Photomicrographs were obtained using digital camera attached to light microscope (Leica DM 4000B and LAS v3.8 software). Epidermal thickness 
was measured in wounded skin and healthy surroundings area by using Image Analyzer Software (ImageJ, NIH) (3 measurements for each compartment/section, 4 sections/animal, $n=7-13$ /group). Structure and organisation of the granulation tissue and/or the scar were observed.

Wound closure and histological studies were performed blindly with regard to treatment.

Measurement of kinin receptors and cytokines $m R N A$ level and circulating $M C P-1$ and SAP Real time PCR was performed to assess B1R and B2R mRNA levels. Total RNA was isolated from the skin, collected at day 11, using TRIzol (Invitrogen, France) and reverse transcribed with superscript II reverse transcriptase as previously described[26]. The cDNAs were amplified and quantified using TaqMan Universal Master Mix and Assays-on-Demand Gene Expression Probes for gene of B1R and B2R (Applied Biosystems, France) in an ABI PRISM-7000 Sequence Detection System (Applied Biosystems, France). Each sample was tested in triplicate. Data were normalized to $18 \mathrm{~S}$ rRNA. Changes in the target gene were calculated by the $2^{-\Delta \Delta C T}$ comparative method for each sample[27]. Same protocol was used to determine levels of MCP-1, TNF-alpha, TGF-beta and IL-6, four major pro-inflammatory cytokines, in wounded skin, using probes from the same supplier. Plasma MCP-1 concentration was also determined in blood samples at 11 days using a mouse MCP-1 enzyme-linked immunosorbent assay kit (Invitrogen, France) according to the manufacturer's instructions. Serum Amyloid P (SAP), an inflammatory marker equivalent to C-reactive protein in man, was quantified at 11 days using a mouse Elisa test kit (Life Diagnosctic, UK).

\section{Keratinocytes and fibroblasts cell culture}

Keratinocytes (human keratinocyte cell line HaCaT; ATCC, Virginia) were cultured in Dulbecco's Modified Eagle Medium (DMEM, Glucose concentration $4500 \mathrm{mg} / \mathrm{l}$, Gibco, LifeTechnologies, UK) supplemented with 10\% Foetal Bovine Serum (FBS, Gibco, LifeTechnologies, UK) and antibiotics (50 U/mL Penicillin, $50 \mathrm{U} / \mathrm{mL}$ Streptomycin, Gibco, LifeTechnologies, UK). Keratinocytes were used between passages 68 and 75 .

Fibroblasts (NIH-3T3 mouse fibroblasts; Sigma-Aldrich, Missouri) were cultured in DMEM supplemented with 5\% New Born Calf Serum (NBCS, Gibco, LifeTechnologies, UK), 5\% FBS and antibiotics according to manufacturer's guidelines. Fibroblasts were used between passages 162 and 171 .

Keratinocytes and fibroblasts were kept at $37^{\circ} \mathrm{C}$ in a $5 \% \mathrm{CO}_{2}$ environment. Culture media were changed every two-day. When the cells reached subconfluence, they were harvested using $0.05 \%$ trypsin-EDTA (Gibco, LifeTechnologies, UK), and fresh culture medium was added for obtaining single cell suspensions used for further study.

Cell proliferation assay Cell proliferation was measured using Quick Cell Proliferation Assay kit (Abcam, Cambridge, MA) according to the manufacturer's instructions[28]. This assay is based on cleavage of the tetrazolium salt WST-1 to formazan by cellular mitochondrial dehydrogenases. Briefly, keratinocytes or fibroblasts were seeded on 96-well plates $\left(1 \times 10^{4}\right.$ cells/well) and incubated with two different concentrations of B1R-ag or B2Rag $\left(1 \times 10^{-6}\right.$ mol. $\mathrm{L}^{-1}$ and $\left.1 \times 10^{-7} \mathrm{~mol} . \mathrm{L}^{-1}\right)$ and/or with B2R-ant $\left(1 \times 10^{-5} \mathrm{~mol} . \mathrm{L}^{-1}\right)$ in DMEM supplemented with 2\% FBS. Cell proliferation was measured after 24, 48, 72 and 96 hours of incubation. Optical density was measured at $440 \mathrm{~nm}$ with a reference wavelength of $650 \mathrm{~nm}$ using a precision microplate reader (iMark Microplate Absorbance Reader, BIORAD). 
Results were expressed as percentage of control (DMEM supplemented with 2\% FBS). Each experiment was performed in duplicate per condition and repeated three times.

Wound closure assay Spreading and migration capabilities of cells were assessed using a scratch assay[29]. Keratinocytes or fibroblasts were seeded on 6 -well plates $\left(3 \times 10^{5}\right.$ cells/well). After reaching confluence, cultures were scratch-wounded with a $0.2 \mathrm{ml}$ sterile pipette tip at the centre of each well and cell debris were removed by PBS washing. For keratinocytes, plates were pre-coated with collagen I (BD Biosciences, California). B1R-ag or B2R-ag $\left(1 \times 10^{-6} \mathrm{~mol} . \mathrm{L}^{-1}\right.$ and $\left.1 \times 10^{-7} \mathrm{~mol} . \mathrm{L}^{-1}\right)$ and/or B2R-ant $\left(1 \times 10^{-5} \mathrm{~mol} . \mathrm{L}^{-1}\right)$ were added in DMEM supplemented with 2\% FBS. Mitomycin C (Sigma-Aldrich, Missouri) $(10 \mu \mathrm{g} / \mathrm{mL})$ was also added in medium to inhibit cellular proliferation. After 15 hours, photographs of the scratch width were taken every 3 hours until closure and scratch closure was quantified by monitoring the front of migration. Results were expressed in percentage of scratch width measured at hour 0. Each experiment was realized in duplicate per condition and repeated four times.

Western blotting Cells were deprived in FBS during 24 hours and then treated 0, 2, 5, 15 and 40 minutes with B2R-ag $\left(1 \times 10^{-6}\right.$ mol. $\left.\mathrm{L}^{-1}\right)$ and/or B2R-ant $\left(1 \times 10^{-5} \mathrm{~mol} . \mathrm{L}^{-1}\right)$. Proteins were extracted from treated-cells using standard protein extraction protocols and were dosed using BCA protein assay (Pierce Protein Biology Products, USA). Fifteen- $\mu$ g proteins were separated on a Mini-PROTEAN TGX gel (Biorad, USA) and membranes were blotted with phospho- and total p44/42 MAPK (Erk-1/2) (Thr202/Tyr204) rabbit antibody (dilution 1/1000; Cell signalling technologies, Danvers, USA). They were exposed to ECL plus western blotting reagents (Biorad, USA) and reactive bands were detected in ImageQuant LAS 4000 (GE Healthcare, France) and quantified using Multi Gauge software 2.0 (FujiFilm, Japan). Each blot was then stripped and re-probed with anti- $\beta$-actin antibodies for data normalization. Results were confirmed by repeating the experiment $3-5$ times.

\section{Statistical analysis}

Data are presented as mean \pm SEM. Statistical analysis was performed using one-way or two-way ANOVA for comparing effect of diabetes and/or treatments in mice. One-way ANOVA was used for comparing effect of treatment on cell migration or proliferation and effect of diabetes on receptor mRNA level. ANOVA was followed by ad-hoc multiple comparison tests. Statistical significance was accepted at $p<0.05$. 


\section{Results}

Treatments did not affect metabolic parameters. Body weight and plasma glucose level of the different groups of mice at the beginning and end of the experiment are presented in Table1. Treatment with B1R-ag, B2R-ag and/or B2R-ant did not affect these parameters (Table 1).

$B 1 R$ and $B 2 R m R N A$ levels are increased in diabetic skin. Analysis of bradykinin receptor levels in healthy skin and wounded area at day 11 demonstrated that B1R mRNA level were increased roughly 3 times in STZ-Diab mice compared to NonDiab mice $(p<0.01)$. Similarly, B2R mRNA level were also increased 2 times compared to Non-Diab mice $(p<0.01)$ (Fig.1).

B1R agonist treatment had no effect on wound closure. B1R-ag treatment had no effect on wound closure in NonDiab mice (Fig.2A) and in STZ-Diab mice (Fig.2B). Moreover, histological analysis showed that B1R activation did not alter skin organisation and had no effect on epidermal thickness, neither in intact surrounding skin nor in wounded skin (data not shown).

$B 2 R$ activation delays wound closure in mice. In NonDiab mice, B2R-ag treatment significantly delayed wound healing from the $1^{\text {st }}$ day of treatment onward (Fig.2A). Cotreatment with the B2R-ant totally abrogated the wound healing delaying effect of B2R-ag. Kinetic profile of wound closure in mice co-treated with B2R-ag and B2R-ant was indistinguishable from PBS-treated mice (Fig.2A). In STZ-Diab mice, wound closure was significantly delayed when compared with NonDiab mice (Fig.2B). On day 11, wounds were healed in NonDiab mice whereas they remained open in STZ-Diab mice $(12.7 \pm 1.2 \%$, $p<0.05)$. In STZ-Diab mice, B2R-ag treatment resulted in a further significant delay in wound healing from the $1^{\text {st }}$ day of treatment onward (Fig.2B). On day 11, wound area was 2.3 times larger in B2R-ag-treated STZ-Diab mice compared to PBS-treated STZ-Diab mice $(\mathrm{p}<0.05)$.

$B 2 R$ blockade improves skin wound healing in two models of diabetic mice. B2R-ant alone had no significant effect on wound healing in NonDiab mice (Fig.2A) but significantly improved skin wound healing in diabetic mice. In STZ-Diab mice, wound area was reduced on the $1^{\text {st }}$ day of B2R-ant treatment and was indistinguishable from NonDiab mice during the 11 days follow-up period (Fig.2B). The beneficial effect of B2R-ant on wound healing was also observed in another diabetic model, db/db-Diab mice. In these mice, B2R-ant significantly reduced wound area during the $11^{\text {th }}$ days of treatment (Fig.2C). On day 11, wound area was 3.2 times smaller in B2R-ant-treated db/db-Diab mice compared to PBStreated $\mathrm{db} / \mathrm{db}$-Diab mice $(\mathrm{p}<0.05)$.

$B 2 R$ activation induces epidermal thickening and skin layer disorganization in wounded skin. B2R activation induced no alteration in intact part of skin in NonDiab and STZ-Diab mice (data not shown). But, in the wound of NonDiab and Diab mice, B2R-ag treatment induced skin layer disorganisation, with a defect in skin and epidermal maturation, hypervascularisation and hypercellularisation of granulation tissue (Fig.3A). In B2R-agtreated NonDiab mice, epidermal thickness of wound area was increased compared to PBStreated mice $(111.1 \pm 8.7 \mu \mathrm{m}$ vs $69.9 \pm 5.7 \mu \mathrm{m} ; p<0.05)$. This effect was abrogated by cotreatment with B2R-ant $(56.3 \pm 8.2 \mu \mathrm{m} ; p<0.05)$ (Fig.3B). In Diab mice, treatment with B2Rag had no further effect on epidermal thickness (Fig.3C). 
$B 2 R$ antagonist treatment restores wounded skin histology in diabetic mice. After B2R-ant treatment alone, the epidermis of Diab-mice was histologically indistinguishable from NonDiab mice (Fig.3A). B2R-ant decreased by $45 \%$ the epidermal thickness of diabetic wounds $(112.4 \pm 21.9 \mu \mathrm{m}$ vs $206.3 \pm 21.6 \mu \mathrm{m} ; p<0.05)$ (Fig.3C).

B2R-ant treatment increases $m R N A$ level of MCP-1 and TNF-alpha. IL-6 and TGF-beta mRNA levels were not influenced by B2R-ag or B2R-ant treatment (data not shown). MCP-1 and TNF-alpha mRNA levels were not influenced by B2R-ag treatment but B2R-ant treatment significantly increased both mRNAs in the wounded skin compared to PBS-treated Diab-mice (Fig.4). However, treatment had no effect on plasma concentration of MCP-1 (Fig.4). Concentration of SAP was below detection level in all groups (data not shown).

$B 2 R$ activation unbalances keratinocyte and fibroblast proliferation in vitro. Treatment with B1R-ag or B2R-ag significantly increased keratinocyte proliferation, assayed using Quick Cell Proliferation Assay kit $(+36 \%$ to $46 \%$ at $48 \mathrm{~h}, p<0.05)$ (Fig.5A). Moreover, fibroblast proliferation was significantly decreased by the B2R-ag $(-33 \%$ at $48 \mathrm{~h}, p<0.05)$ but was not altered by the B1R-ag (Fig.5B). These B2R-ag effects on cell proliferation were abolished by co-treatment with B2R-ant (Fig.5). B2R-ant alone had no effect on cell proliferation.

$B 2 R$ activation stimulates keratinocyte but not fibroblast migration. Figure 6 shows that keratinocyte migration, assessed using scratch assay, was significantly stimulated with B2Rag during the 30 hours scratch closure process and independently of the dose used (wound closure $+32 \%$ compared to medium alone after $24 \mathrm{~h}, p<0.05$ ). This effect was abolished in presence of the B2R-ant (Fig.6B). B2R-ant alone or B1R-ag had no effect on cell migration (Fig.6B). B2R-ag treatment had no effect on fibroblast migration (data not shown).

$B 2 R$ activation induces ERK phosphorylation in keratinocytes. B2R-ag induced phosphorylation of ERK-1/2 in keratinocytes. Peak phosphorylation occurred 5 to $40 \mathrm{~min}$ after stimulation $(p<0.05)$ and thereafter, the phosphorylation level gradually decreased $(60-$ 120 min). This effect was blocked by B2R-ant co-treatment (Fig.7). 


\section{Discussion}

The main findings of the present study are that kinin B2R activation delays healing in nondiabetic and diabetic mouse skin wound models. Treatment with a selective B2R antagonist accelerates skin wound repair in diabetic mice. The healing effect of $\mathrm{B} 2 \mathrm{R}$ antagonist was consistent in two different murine models of diabetes, close to either type 1 or type 2 human diabetes. The deleterious effects of B2R activity in the wounded skin may involve unbalancing of keratinocyte and fibroblast proliferation during the re-epithelialisation and scar remodelling phases after injury.

Previous reports indicated that B1R and B2R are present in healthy human skin and in skin of patients with cutaneous wound or proliferative skin diseases[12-14]. We show that both receptors are present in murine skin and are upregulated by diabetes mellitus.

Kinins can exert their biological actions through these two types of $G$ protein-coupled membrane receptors. While the $\mathrm{B} 2 \mathrm{R}$ is constitutively present in most tissues and mediates the main effect of kinins, the B1R is considered as being mainly inducible and its functions are less well understood. Interestingly, we recently showed that B1R activation protects the heart against ischemia damage[30] and has pro-angiogenic effects in a diabetic mouse model of hindlimb ischemia[10]. However in the skin, B1R activation had no effect on wound healing in mice, diabetic or non-diabetic. This receptor does not seem to be importantly involved in control of skin trophicity in diabetes, despite its strong induction by chronic hyperglycaemia.

By contrast, B2R activation disorganized the architecture of the wound, increased epidermis thickness and significantly delayed wound healing in mice. The deleterious effect of B2R activation on wound repair was observed in both non-diabetic and diabetic mice and was additive to the effect of diabetes. Co-treatment with a specific B2R antagonist abrogated the effects of $\mathrm{B} 2 \mathrm{R}$ agonist administration indicating that these effects were truly due to $\mathrm{B} 2 \mathrm{R}$ activation.

Wound healing involves tightly regulated humoral and cellular processes. Alteration of these timely-controlled processes by chronic hyperglycaemia expands tissue damage and delays tissue repair[31]. After a cutaneous injury, the healing process can be divided into four successive, overlapping phases: coagulation, inflammation, cell migration and proliferation, and remodelling. Kinins, through B2R activation, could likely influence several of these phases.

The first steps of wound healing are haemostasis and inflammation[31]. Kinins, through vascular endothelium activation, have anti-clotting and profibrinolytic effects[32,33], increase blood flow and trigger leucocyte migration[34]. In our study, pharmacological manipulation of B2R activity influenced wound repair already on the first day of follow-up after surgery. This observation suggests that kinins influence the initial phase of wound repair. The absence of effect of B2R agonist treatment on inflammatory markers in plasma or on cytokine gene expression in scar suggests that inflammation does not play an important role in B2R effect in wounded skin. On the other hand, B2R antagonist induced gene expression of MCP-1 and TNF-alpha, two cytokines previously shown to be involved in wound repair that may thus mediate, at least in part, the beneficial effect of B2R inhibition [35,36]. The mechanism of MCP-1 and TNF-alpha induction during B2R inhibition remains however undocumented.

Kinins can also influence late phases of healing. Our histological results show that B2R agonist induced skin disorganisation and increased epidermal thickness and hypercellular granulation tissue. Moreover, previous studies suggested that bradykinin enhances keratinocyte motility[37] and differentiation even if effect on cell proliferation is 
unclear[13,15]. All these findings suggest that kinins influence proliferative and remodelling phases of healing. In this context, we studied in vitro effect of $\mathrm{B} 2 \mathrm{R}$ activation on proliferation and migration of the two major cell types involved in scar formation: keratinocytes and fibroblasts. Our results show that B2R activation inhibited fibroblast proliferation but increased keratinocyte proliferation and migration in a cell layer injury model. Despite limitation in extrapolation of data from in vitro to in vivo settings due to use of established cell lines and different species, these effects of B2R agonist are consistent with the wound repair delaying effect observed in mice. Indeed, accumulation of fibroblasts, formation of granulation tissue, reconstitution of the dermis and reformation of an intact epidermis via keratinocyte migration and proliferation are important features of the wound healing process[31]. Skin layer disorganization, involving stratum corneum, epidermis and dermis, observed in mice treated with B2R agonist, especially in diabetic mice, may thus reflect unbalance between hypo-proliferation of fibroblasts and hyper-proliferation of keratinocytes, impairing healing. Stimulation of keratinocyte proliferation and migration in vitro by B2R activation is in line with the thickening of epidermis observed in B2R agonist treated mice.

B2R activation effects on keratinocytes were associated with ERK-1/2 phosphorylation. This result is in agreement with previous observations showing that keratinocyte migration, proliferation and wound re-epithelialization involve ERK activation[38-40] and confirms the importance of this pathway in keratinocyte functionality.

The deleterious effect of B2R stimulation on wound healing was additive to the effect of diabetes. Abnormal keratinocyte and fibroblast migration, proliferation and differentiation, and decreased vascularisation contribute to delayed wound healing in diabetic patients[4,41]. In these patients, keratinocytes in epidermis of chronic ulcers are highly proliferative[42]. B2R agonist treatment probably worsened keratinocyte hyper-proliferation due to diabetes and stimulated migration, resulting in abnormal scar remodelling.

Interestingly, whereas B2R antagonist alone had no effect on the wounded skin in nondiabetic mice, it significantly accelerated wound repair in diabetic mice. Indeed, B2R blockade restored the normal proliferation and maturation pattern of the wounded epidermis in a murine model of type 1 diabetes (STZ). The beneficial effect on wound healing of B2R antagonist was extended to a second diabetic mouse model, closer to type 2 human diabetes ( $\mathrm{db} / \mathrm{db}$ mice). These observations indicate that endogenous kinins exert deleterious effects opposing wound repair in diabetic skin. The lack of effect of B2R antagonist in non-diabetic mice may be explained by low kinins bioavailability and/or reduced B2R synthesis in the skin in normoglycaemic condition. By contrast, in diabetes, B2R synthesis is upregulated in the skin and kinins production may also be enhanced.

The study highlights the organ specificity and duality of action of B2R. B2R activation simultaneously aggravates tissue damage in the wounded skin and reduces ischemic or hyperglycaemic tissue damage in heart and kidney[11,26,43]. Kinins are mainly inactivated in the circulation by the angiotensin I-converting enzyme (ACE/kininase II). ACE inhibitors increase kinin biodisponibility and are largely used clinically in a number of cardiovascular and renal indications, including in diabetes. No side effect related to impairment of skin wound healing or aggravation of diabetic ulcers has however been reported in clinical trials with ACE inhibitors. ACE inhibitors have not been studied experimentally in wound healing but angiotensin II type 1 receptor (AT1R) blockers and AT1R gene inactivated mice have been shown to display delayed skin wound healing in both non-diabetic and diabetic conditions[44]. As AT1R inhibition triggers angiotensin II type 2 receptor (AT2R) stimulation and subsequent kinin formation and B2R activation[45,46], kinins might be 
involved in the deleterious effect of AT1R blockade observed experimentally in the skin, although this remains speculative. Like for ACE inhibitors no side effect related to skin healing has been observed in clinical trials with AT1R blockers. In our study, the absence of effect of B2R antagonist in non-diabetic mice may be explained by low kinins bioavailability and/or reduced $\mathrm{B} 2 \mathrm{R}$ synthesis in the skin in normoglycaemic condition. By contrast, in diabetes B2R synthesis is upregulated in the skin and kinin production may also be enhanced. Kinins are produced by tissue kallikrein and/or activated plasma prekallikrein. Tissue kallikrein is present in the skin[12,14,15]. However, in tissue kallikrein deficient mice[7,47], either rendered diabetic or not, we did not observe any alteration in wound repair, suggesting that tissue kallikrein is not importantly involved in kinin production in the wounded skin (unpublished results). On the other hand, plasma prekallikrein increases in diabetes[48] and this enzyme might be responsible for kinins production in the wounded skin, although this remains speculative.

In conclusion, $\mathrm{B} 2 \mathrm{R}$ but not $\mathrm{B} 1 \mathrm{R}$ activation exerts deleterious effects in the wounded mouse skin resulting in delayed healing, especially in diabetic animals. B1R and B2R are upregulated by diabetes in skin. Treatment with a B2R antagonist accelerates wound repair in two different mouse models of diabetes. Improving skin healing is still a therapeutic issue in diabetic patients, especially for treatment of foot ulcers. These results indicate that investigation of kinin B2 antagonism in human diabetic wound healing is warranted, and that kinin B2R antagonism could become a new treatment for cutaneous injury. It is worth noting that icatibant, a first generation pseudopeptide kinin B2R antagonist synthesized decades ago[24], has recently been approved for clinical use in an unrelated indication, angioedema [49]. 


\section{Clinical perspectives}

- Impairment of skin wound repair is a major complication of diabetes, favouring development of foot ulcers and contributing to their poor prognosis. Improving skin healing is a therapeutic issue in diabetic patients.

- Our study revealed that treatment with a kinin B2-receptor antagonist normalizes wound repair in two mouse models of diabetes, close to either type 1 or type 2 human diabetes.

- B2-receptor antagonism, already approved clinically in an unrelated indication, may become new treatment for cutaneous injury in diabetic patients.

\section{Author contributions}

D.D., L.W, V.D., F.A-G., R.R., N.B. made substantial contribution to the design, acquisition and analysis of data and have drafted the manuscript. C.C., C.T. made substantial contribution to acquisition of data. All authors have reviewed and approved the final version.

\section{Acknowledgments}

The authors thank M. Moreau (Cordeliers Research Center, Paris) and the crew of the Functional Exploration Center (Cordeliers Research Center, Paris) for technical assistance and support in mice studies. We are very grateful to Pr P. Bruneval (anatomy and pathology department, European Hospital Georges Pompidou, Paris France) for his expert help in histological analysis. We also thank J.P. Girolami for his expertise.

\section{Funding}

This work was supported by Société Francophone du Diabète, Institut National de la Santé Et de la Recherche Médicale, Paris-Descartes University, Pierre and Marie Curie University.

\section{Duality of interest}

The authors declare that there is no duality of interest associated with this manuscript. 


\section{References}

1. Ramsey SD, Newton K, Blough D, McCulloch DK, Sandhu N, et al. (1999) Incidence, outcomes, and cost of foot ulcers in patients with diabetes. Diabetes Care 22: 382-387.

2. Bartus CL, Margolis DJ (2004) Reducing the incidence of foot ulceration and amputation in diabetes. Curr Diab Rep 4: 413-418.

3. Boulton AJ, Vileikyte L, Ragnarson-Tennvall G, Apelqvist J (2005) The global burden of diabetic foot disease. Lancet 366: 1719-1724.

4. Brem H, Tomic-Canic M (2007) Cellular and molecular basis of wound healing in diabetes. J Clin Invest 117: 1219-1222.

5. Falanga V (2005) Wound healing and its impairment in the diabetic foot. Lancet 366: 17361743.

6. Couture R, Blaes N, Girolami JP (2014) Kinin receptors in vascular biology and pathology. Curr Vasc Pharmacol 12: 223-248.

7. Waeckel L, Potier L, Richer C, Roussel R, Bouby N, et al. (2013) Pathophysiology of genetic deficiency in tissue kallikrein activity in mouse and man. Thromb Haemost 110: 476-483.

8. Furchgott RF, Vanhoutte PM (1989) Endothelium-derived relaxing and contracting factors. FASEB J 3: 2007-2018.

9. Couture R, Harrisson M, Vianna RM, Cloutier F (2001) Kinin receptors in pain and inflammation. Eur J Pharmacol 429: 161-176.

10. Desposito D, Potier L, Chollet C, Gobeil F, Jr., Roussel R, et al. (2015) Kinin receptor agonism restores hindlimb postischemic neovascularization capacity in diabetic mice. J Pharmacol Exp Ther 352: 218-226.

11. Kayashima Y, Smithies O, Kakoki M (2012) The kallikrein-kinin system and oxidative stress. Curr Opin Nephrol Hypertens 21: 92-96.

12. Komatsu N, Takata M, Otsuki N, Toyama T, Ohka R, et al. (2003) Expression and localization of tissue kallikrein mRNAs in human epidermis and appendages. J Invest Dermatol 121: 542-549.

13. Vidal MA, Astroza A, Matus CE, Ehrenfeld P, Pavicic F, et al. (2005) Kinin B2 receptorcoupled signal transduction in human cultured keratinocytes. J Invest Dermatol 124: 178-186.

14. Schremmer-Danninger E, Naidoo S, Neuhof C, Valeske K, Snyman C, et al. (2004) Visualisation of tissue kallikrein, kininogen and kinin receptors in human skin following trauma and in dermal diseases. Biol Chem 385: 1069-1076.

15. Poblete MT, Reynolds NJ, Figueroa CD, Burton JL, Muller-Esterl W, et al. (1991) Tissue kallikrein and kininogen in human sweat glands and psoriatic skin. Br J Dermatol 124: 236-241.

16. Milia AF, Del Rosso A, Pacini A, Manetti M, Marrelli A, et al. (2005) Differential expression of tissue kallikrein in the skin of systemic sclerosis. Histol Histopathol 20: 415-422.

17. Pietrovski EF, Paludo KS, Mendes DA, Guimaraes Fde S, Veiga SS, et al. (2011) B1 and B2 kinin receptor participation in hyperproliferative and inflammatory skin processes in mice. J Dermatol Sci 64: 23-30.

18. Warren JB, Loi RK (1995) Captopril increases skin microvascular blood flow secondary to bradykinin, nitric oxide, and prostaglandins. FASEB J 9: 411-418.

19. Johnson MS, Ryals JM, Wright DE (2008) Early loss of peptidergic intraepidermal nerve fibers in an STZ-induced mouse model of insensate diabetic neuropathy. Pain 140: 3547. 
20. Ebrahimian TG, Squiban C, Roque T, Lugo-Martinez H, Hneino M, et al. (2012) Plasminogen activator inhibitor-1 controls bone marrow-derived cells therapeutic effect through MMP9 signaling: role in physiological and pathological wound healing. Stem Cells 30: 1436-1446.

21. Balaji S, Lesaint M, Bhattacharya SS, Moles C, Dhamija Y, et al. (2014) Adenoviralmediated gene transfer of insulin-like growth factor 1 enhances wound healing and induces angiogenesis. J Surg Res. 190(1):367-77.

22. Cote J, Savard M, Bovenzi V, Belanger S, Morin J, et al. (2009) Novel kinin B1 receptor agonists with improved pharmacological profiles. Peptides 30: 788-795.

23. Belanger S, Bovenzi V, Cote J, Neugebauer W, Amblard M, et al. (2009) Structureactivity relationships of novel peptide agonists of the human bradykinin B2 receptor. Peptides 30: 777-787.

24. Wirth K, Hock FJ, Albus U, Linz W, Alpermann HG, et al. (1991) Hoe 140 a new potent and long acting bradykinin-antagonist: in vivo studies. Br J Pharmacol 102: 774-777.

25. Tschope C, Seidl U, Reinecke A, Riester U, Graf K, et al. (2003) Kinins are involved in the antiproteinuric effect of angiotensin-converting enzyme inhibition in experimental diabetic nephropathy. Int Immunopharmacol 3: 335-344.

26. Bodin S, Chollet C, Goncalves-Mendes N, Gardes J, Pean F, et al. (2009) Kallikrein protects against microalbuminuria in experimental type I diabetes. Kidney Int 76: 395403.

27. Livak KJ, Schmittgen TD (2001) Analysis of relative gene expression data using real-time quantitative PCR and the 2(-Delta Delta C(T)) Method. Methods 25: 402-408.

28. Guo S, Al-Sadi R, Said HM, Ma TY (2013) Lipopolysaccharide causes an increase in intestinal tight junction permeability in vitro and in vivo by inducing enterocyte membrane expression and localization of TLR-4 and CD14. Am J Pathol 182: 375387.

29. Fronza M, Heinzmann B, Hamburger M, Laufer S, Merfort I (2009) Determination of the wound healing effect of Calendula extracts using the scratch assay with 3T3 fibroblasts. J Ethnopharmacol 126: 463-467.

30. Potier L, Waeckel L, Vincent MP, Chollet C, Gobeil F, Jr., et al. (2013) Selective kinin receptor agonists as cardioprotective agents in myocardial ischemia and diabetes. $\mathrm{J}$ Pharmacol Exp Ther 346: 23-30.

31. Li J, Chen J, Kirsner R (2007) Pathophysiology of acute wound healing. Clin Dermatol 25: 9-18.

32. Brown NJ, Gainer JV, Murphey LJ, Vaughan DE (2000) Bradykinin stimulates tissue plasminogen activator release from human forearm vasculature through $\mathrm{B}(2)$ receptordependent, NO synthase-independent, and cyclooxygenase-independent pathway. Circulation 102: 2190-2196.

33. Murphey LJ, Malave HA, Petro J, Biaggioni I, Byrne DW, et al. (2006) Bradykinin and its metabolite bradykinin 1-5 inhibit thrombin-induced platelet aggregation in humans. J Pharmacol Exp Ther 318: 1287-1292.

34. Blaes N, Girolami JP (2013) Targeting the 'Janus face' of the B2-bradykinin receptor. Expert Opin Ther Targets 17: 1145-1166.

35. Wood S, Jayaraman V, Huelsmann EJ, Bonish B, Burgad D, et al. (2014) Proinflammatory chemokine CCL2 (MCP-1) promotes healing in diabetic wounds by restoring the macrophage response. PLoS One 9: e91574.

36. Rapala K (1996) The effect of tumor necrosis factor-alpha on wound healing. An experimental study. Ann Chir Gynaecol Suppl 211: 1-53. 
37. Coutant KD, Corvaia N, Ryder NS (1997) Bradykinin induces actin reorganization and enhances cell motility in HaCaT keratinocytes. Biochem Biophys Res Commun 237: 257-261.

38. Gao L, Chao L, Chao J (2010) A novel signaling pathway of tissue kallikrein in promoting keratinocyte migration: activation of proteinase-activated receptor 1 and epidermal growth factor receptor. Exp Cell Res 316: 376-389.

39. Li W, Henry G, Fan J, Bandyopadhyay B, Pang K, et al. (2004) Signals that initiate, augment, and provide directionality for human keratinocyte motility. J Invest Dermatol 123: 622-633.

40. Pastore S, Mascia F, Mariani V, Girolomoni G (2008) The epidermal growth factor receptor system in skin repair and inflammation. J Invest Dermatol 128: 1365-1374.

41. Albiero M, Menegazzo L, Boscaro E, Agostini C, Avogaro A, et al. (2011) Defective recruitment, survival and proliferation of bone marrow-derived progenitor cells at sites of delayed diabetic wound healing in mice. Diabetologia 54: 945-953.

42. Usui ML, Mansbridge JN, Carter WG, Fujita M, Olerud JE (2008) Keratinocyte migration, proliferation, and differentiation in chronic ulcers from patients with diabetes and normal wounds. J Histochem Cytochem 56: 687-696.

43. Griol-Charhbili V, Messadi-Laribi E, Bascands JL, Heudes D, Meneton P, et al. (2005) Role of tissue kallikrein in the cardioprotective effects of ischemic and pharmacological preconditioning in myocardial ischemia. FASEB J 19: 1172-1174.

44. Yahata Y, Shirakata Y, Tokumaru S, Yang L, Dai X, et al. (2006) A novel function of angiotensin II in skin wound healing. Induction of fibroblast and keratinocyte migration by angiotensin II via heparin-binding epidermal growth factor (EGF)-like growth factor-mediated EGF receptor transactivation. J Biol Chem 281: 13209-13216.

45. Siragy HM, Jaffa AA, Margolius HS, Carey RM (1996) Renin-angiotensin system modulates renal bradykinin production. Am J Physiol 271: R1090-1095.

46. Messadi-Laribi E, Griol-Charhbili V, Pizard A, Vincent MP, Heudes D, et al. (2007) Tissue kallikrein is involved in the cardioprotective effect of AT1-receptor blockade in acute myocardial ischemia. J Pharmacol Exp Ther 323: 210-216.

47. Meneton P, Bloch-Faure M, Hagege AA, Ruetten H, Huang W, et al. (2001) Cardiovascular abnormalities with normal blood pressure in tissue kallikrein-deficient mice. Proc Natl Acad Sci U S A 98: 2634-2639.

48. Feener EP, Zhou Q, Fickweiler W (2013) Role of plasma kallikrein in diabetes and metabolism. Thromb Haemost 110: 434-441.

49. Cicardi M, Banerji A, Bracho F, Malbran A, Rosenkranz B, et al. (2010) Icatibant, a new bradykinin-receptor antagonist, in hereditary angioedema. N Engl J Med 363: 532541. 
TABLE 1: Weight and blood glucose level of different experimental groups at time of wounding (beginning of the experiment) and 11 days after wounding (end of the experiment).

\begin{tabular}{|c|c|c|c|c|c|}
\hline & \multirow[b]{2}{*}{$\mathrm{n}$} & \multicolumn{2}{|c|}{ Beginning of experiment } & \multicolumn{2}{|c|}{ End of experiment } \\
\hline & & $\begin{array}{l}\text { Weight } \\
\text { (g) }\end{array}$ & $\begin{array}{l}\text { Blood glucose } \\
(\mathrm{mg} / \mathrm{dL})\end{array}$ & $\begin{array}{l}\text { Weight } \\
\text { (g) }\end{array}$ & $\begin{array}{l}\text { Blood glucose } \\
\text { (mg/dL) }\end{array}$ \\
\hline NonDiab & 30 & $26.2 \pm 0.5$ & $178 \pm 6$ & $25.7 \pm 0.4$ & $156 \pm 12$ \\
\hline \multicolumn{6}{|l|}{ STZ-Diab } \\
\hline PBS-treated & 22 & $23.3 \pm 0.2$ & $471 \pm 17 * *$ & $22.8 \pm 0.3$ & $464 \pm 13 * *$ \\
\hline B1R-ag-treated & 21 & $23.5 \pm 0.2$ & $500 \pm 17 * *$ & $23.9 \pm 0.2$ & $452 \pm 21 * *$ \\
\hline B2R-ag-treated & 20 & $22.5 \pm 0.2$ & $456 \pm 26 * *$ & $23.3 \pm 0.3$ & $438 \pm 32 * *$ \\
\hline B2R-ant-treated & 7 & $23.0 \pm 0.3$ & $460 \pm 34 * *$ & $24.0 \pm 0.5$ & $453 \pm 26 * *$ \\
\hline \multicolumn{6}{|l|}{ db/db mice } \\
\hline PBS-treated & 10 & $43.2 \pm 0.9$ & $386 \pm 25 * *$ & $44.5 \pm 1.2$ & $379 \pm 27 * *$ \\
\hline B2R-ant-treated & 10 & $43.5 \pm 0.4$ & $385 \pm 34 * *$ & $45.8 \pm 0.8$ & $394 \pm 29 * *$ \\
\hline
\end{tabular}

** $p<0.001$ : glucose level in all Diab groups vs NonDiab. NS among Diab groups. 


\section{Figure legends}

Fig.1: B1R and B2R mRNA levels are increased in diabetic skin.

Kinin receptor mRNA level in non-diabetic and diabetic mouse skin (wounded or not), measured by RT-qPCR. Data were normalized to $18 \mathrm{~S}$ rRNA. Data are mean $\pm \mathrm{SEM}$, $\mathrm{n}=7 /$ group. ${ }^{* *}: p<0.01$ Diab vs NonDiab

Fig.2: B2R but not B1R activation influences wound healing in NonDiab mice and in Diab mice.

Representative photographs of wound area at day 0 and 11 and time course of wound closure (A: NonDiab mice; B: STZ-Diab mice; C: db/db-Diab mice). Results are expressed in percentage of initial wound area at day 0 . Data are mean \pm SEM, $\mathrm{n}=7-30$ /group. ${ }^{*}: p<0.05$ and **: $p<0.01$ vs PBS-control in each series; $\$: p<0.05$ and $\$ \$: p<0.01$ Diab vs NonDiab.

Fig.3: B2R but not B1R activation increases epidermal thickness and worsens skin disorganization in wounded skin in NonDiab and STZ-Diab mice.

(A) Representative photographs of Massons's trichrome-stained sections of wounds at day 11 (2x;10x; 25xmagnification) documenting change in the skin organization. Note thickness of epidermis and vascularisation and cellularisation of dermis. Bar $=1 \mathrm{~mm}$. Blue arrows show hypercellularisation, black arrows hypervascularisation, dashed blue arrow epidermal thickening and dashed black arrows skin layer disorganisation. (B) Quantification of epidermal thickness of the scar in NonDiab mice. (C) Quantification of epidermal thickness of the scar in STZ-Diab mice. Data are mean \pm SEM, $n=7 /$ group.

Fig.4: B2R-ant treatment increases mRNA level of MCP-1 and TNF-alpha.

(A) MCP-1 and TNF-alpha mRNA level in scar of STZ-Diab mice treated with the B2R-ag or B2R-ant, measured by RT-qPCR. Data were normalized to $18 \mathrm{~S}$ rRNA. (B) MCP-1 protein level in plasma of these mice. Data are mean \pm SEM, $n=5-6 /$ group.

Fig.5: B2R activation unbalances keratinocytes/fibroblasts proliferation.

Cell proliferation after $48 \mathrm{~h}$ of treatment with B1R-ag, B2R-ag and/or B2R-ant (A: keratinocytes; B: fibroblasts) at indicated doses. Data are mean $\pm \mathrm{SEM}, \mathrm{n}=6$ wells/group.

Fig.6: B2R but not B1R activation stimulates keratinocyte migration.

(A) Representative images of keratinocytes migration (10×magnification) at 0, 15 and 30h post scratch. Scratch area is delimited by black box. (B) Scratch closure after $24 \mathrm{~h}$ of treatment. Data are mean \pm SEM and expressed as percentage of scratch width measured at $0 \mathrm{~h}$. Each data point represents $n=8$ wells.

Fig.7: B2R activation induces ERK phosphorylation in keratinocytes.

Phosphorylation of ERK-1/2 on keratinocyte lysates assessed by Western blotting after 0,2 , 5,15 and 40 minutes of tretament with B2R-ag $\left(1 \times 10^{-6} \mathrm{~mol}^{-\mathrm{L}^{-1}}\right)$ and/or B2R-ant $\left(1 \times 10^{-5} \mathrm{~mol} . \mathrm{L}^{-}\right.$ $\left.{ }^{1}\right)$. Results are representative of $3-5$ independent experiments. ${ }^{*}: p<0.05$ vs $\mathrm{t}=0 \mathrm{~min}$. 


\section{Summary statements}

Kinin B2-receptor activation impairs skin wound healing in mice, in part through imbalance of keratinocyte/fibroblast proliferation. Such activation occurs in diabetes and contributes to delaying wound healing. B2-receptor blockade restores normal wound healing pattern in mouse models of diabetes. 
Figure 1

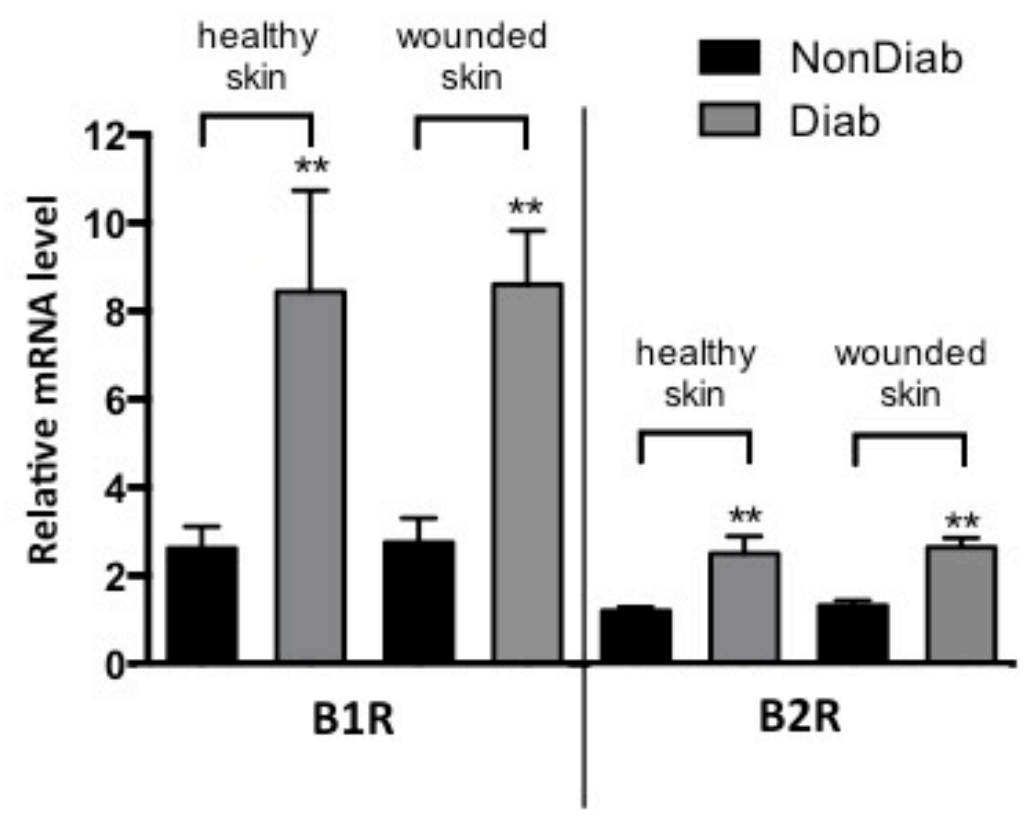




\section{Figure 2}

A
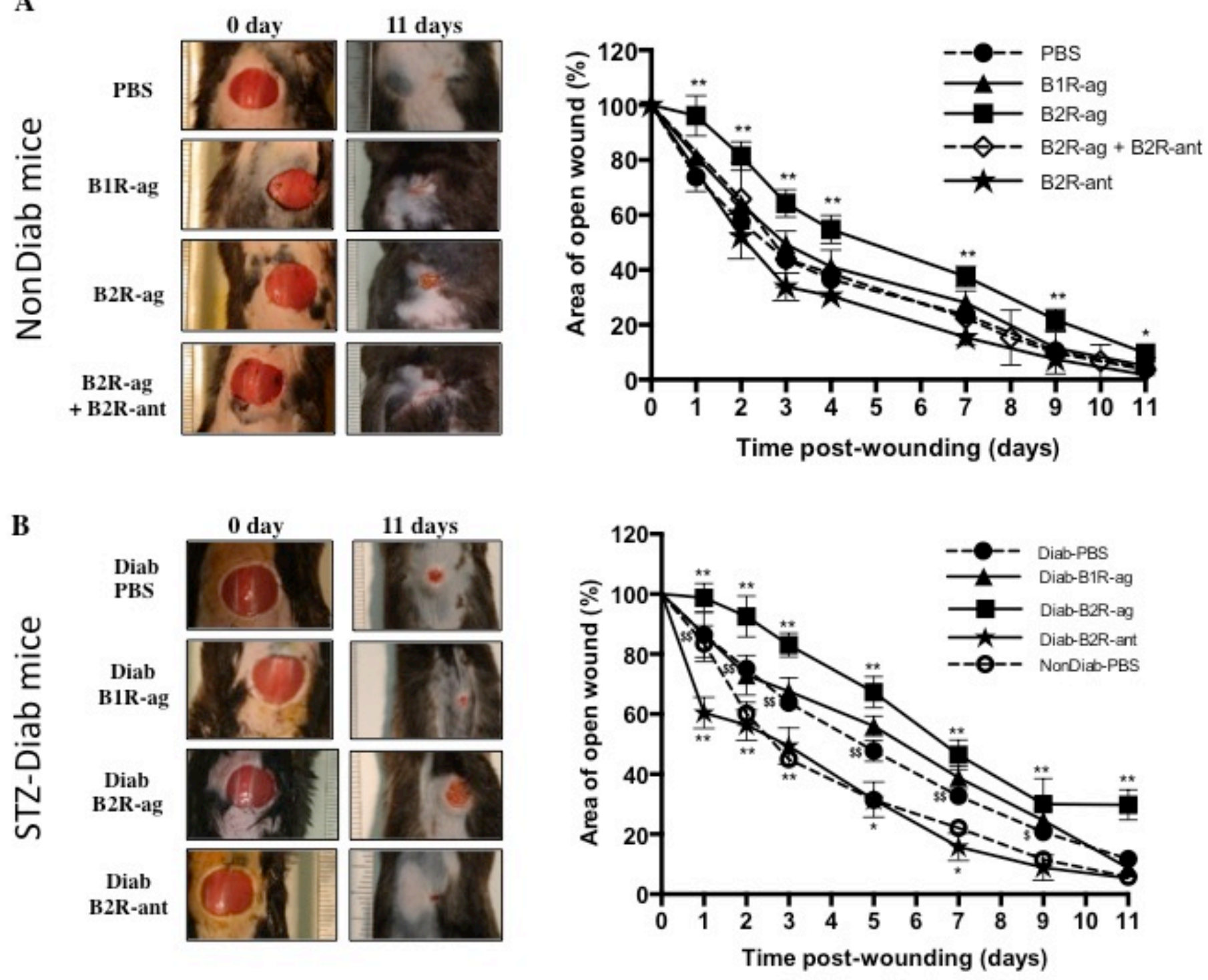

C

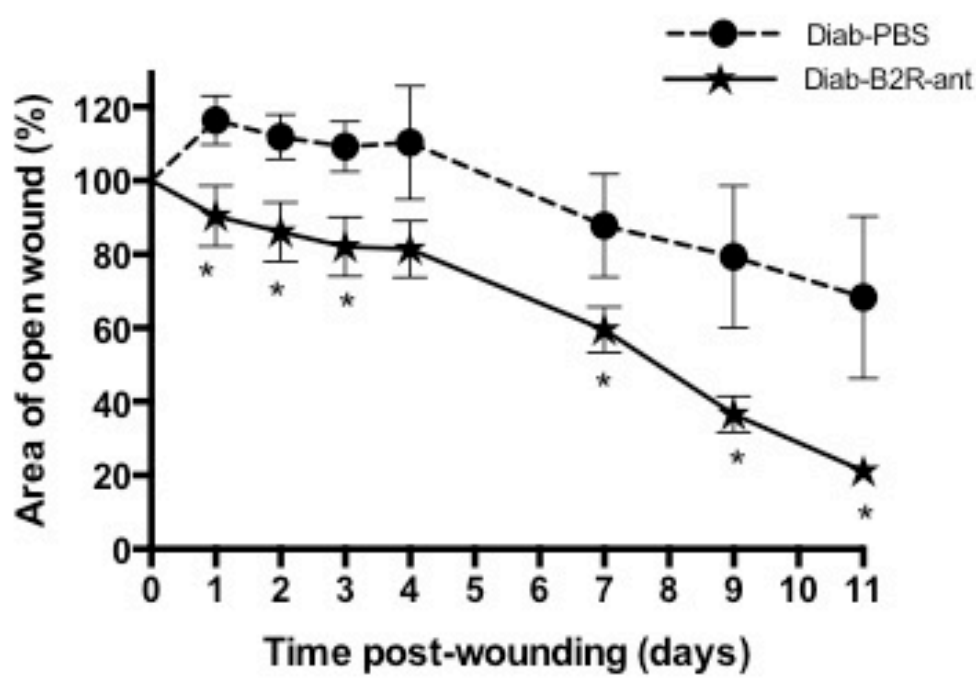


Figure 3

A Nondiab
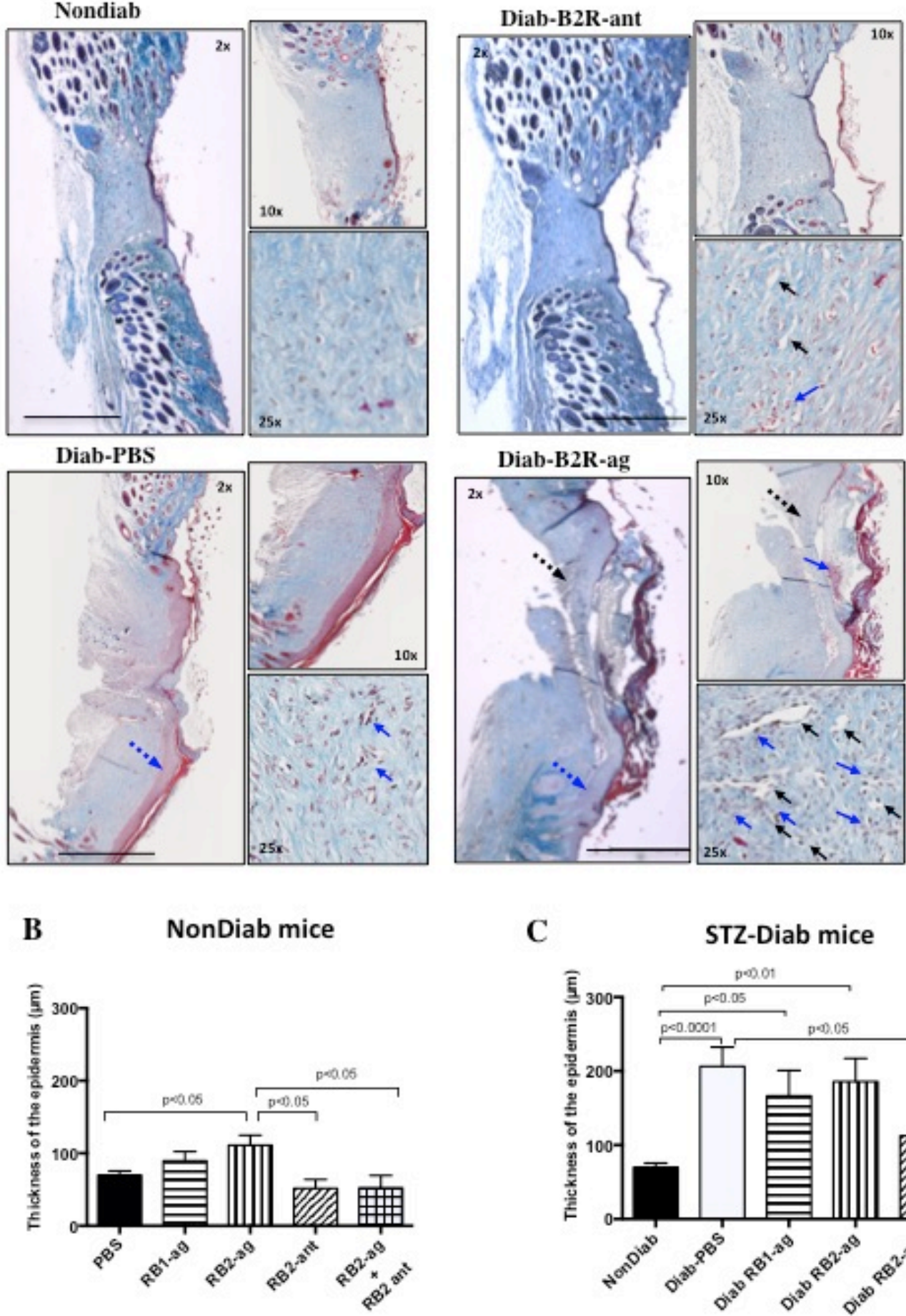

C STZ-Diab mice

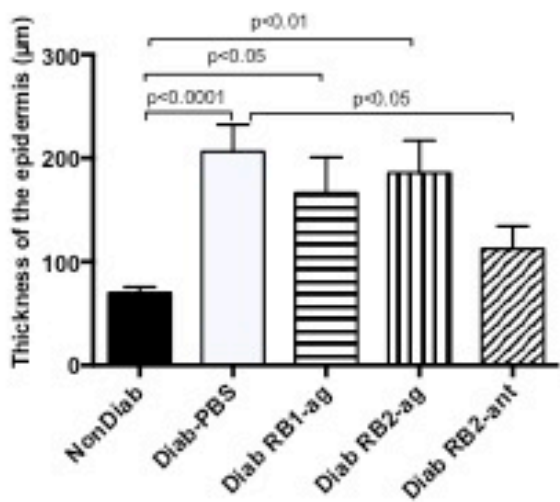


Figure 4

A

MCP-1

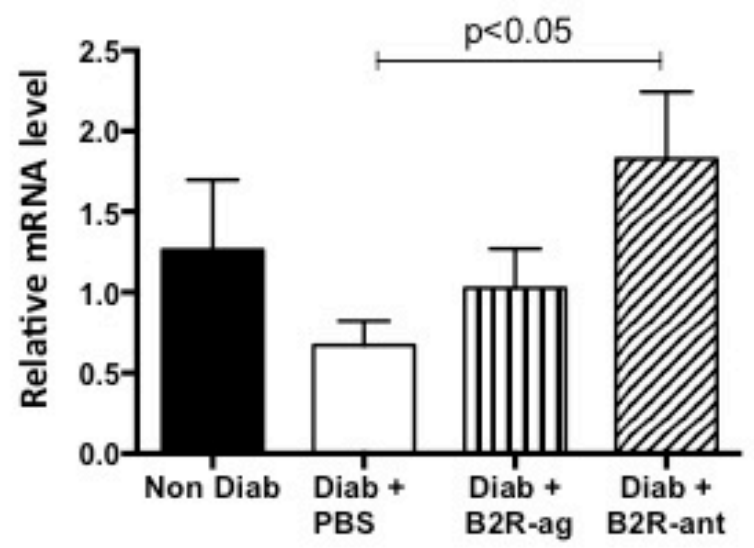

B

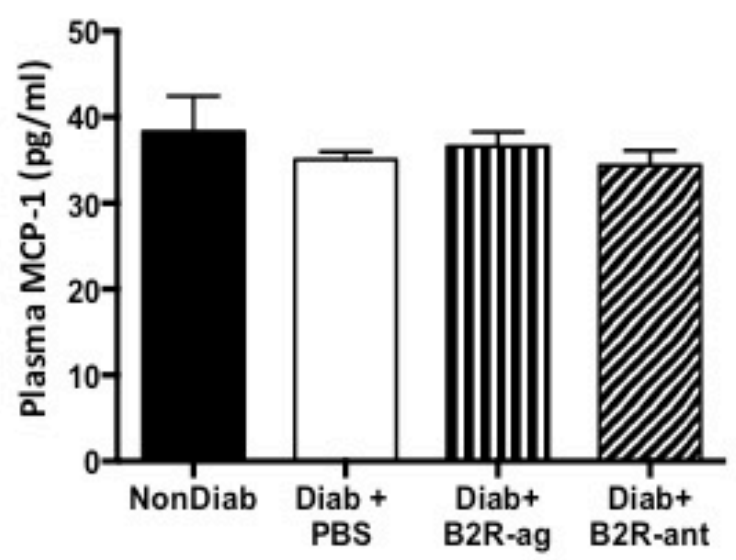

TNFa

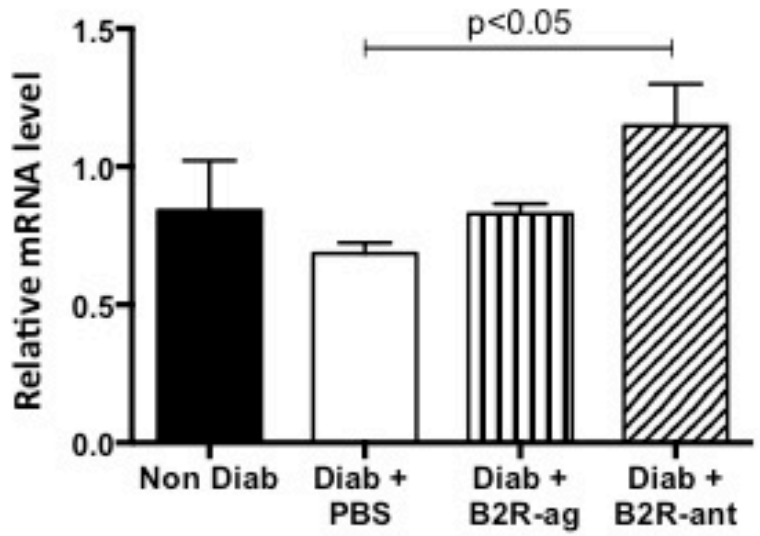


Figure 5

A

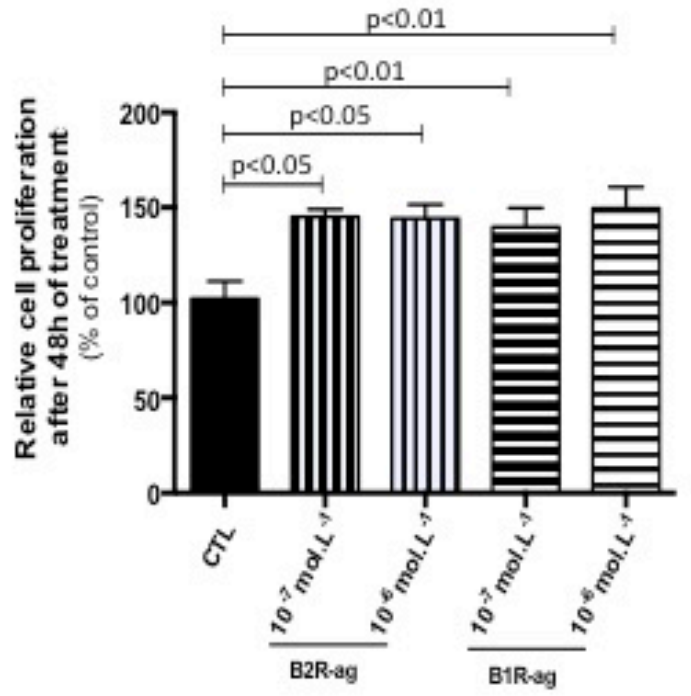

B

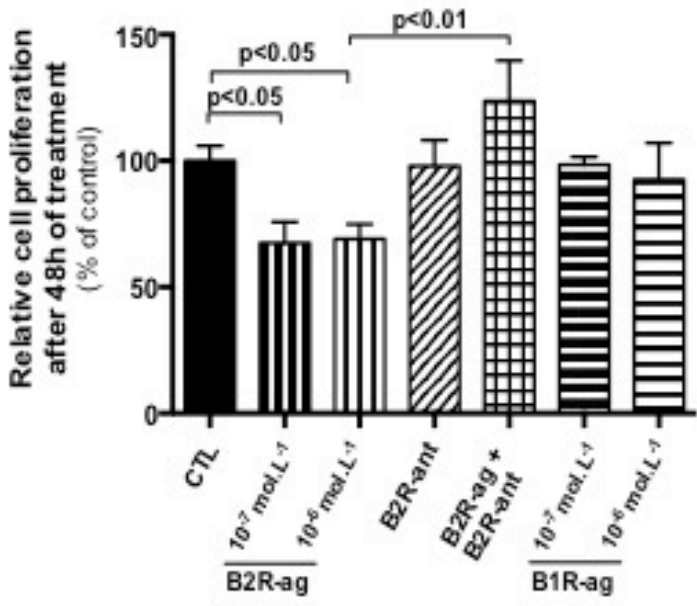


Figure 6

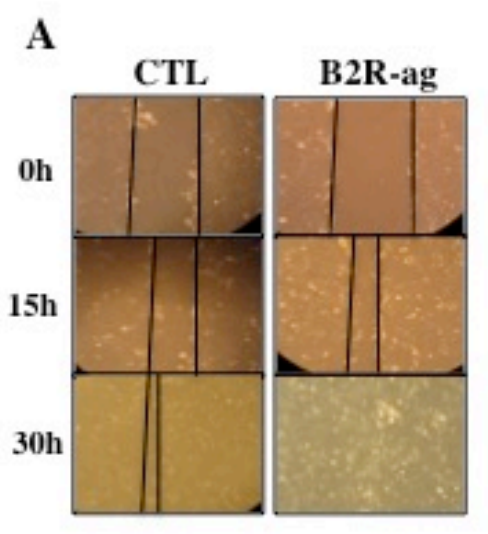

B

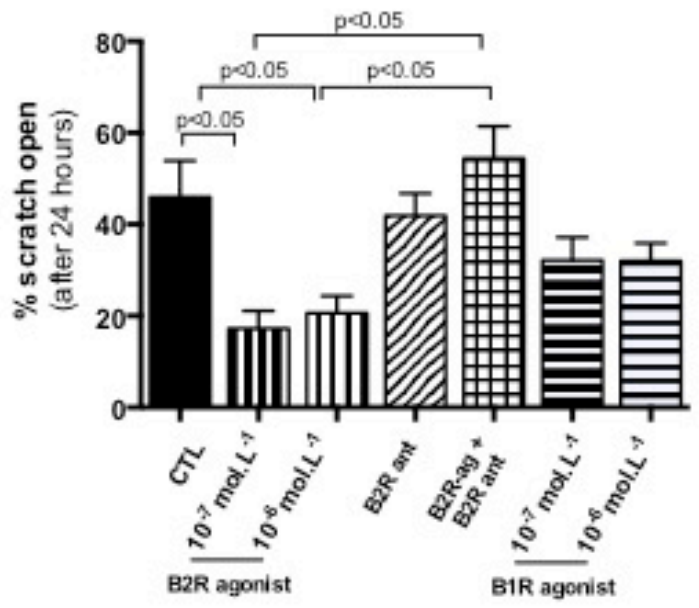


Figure 7
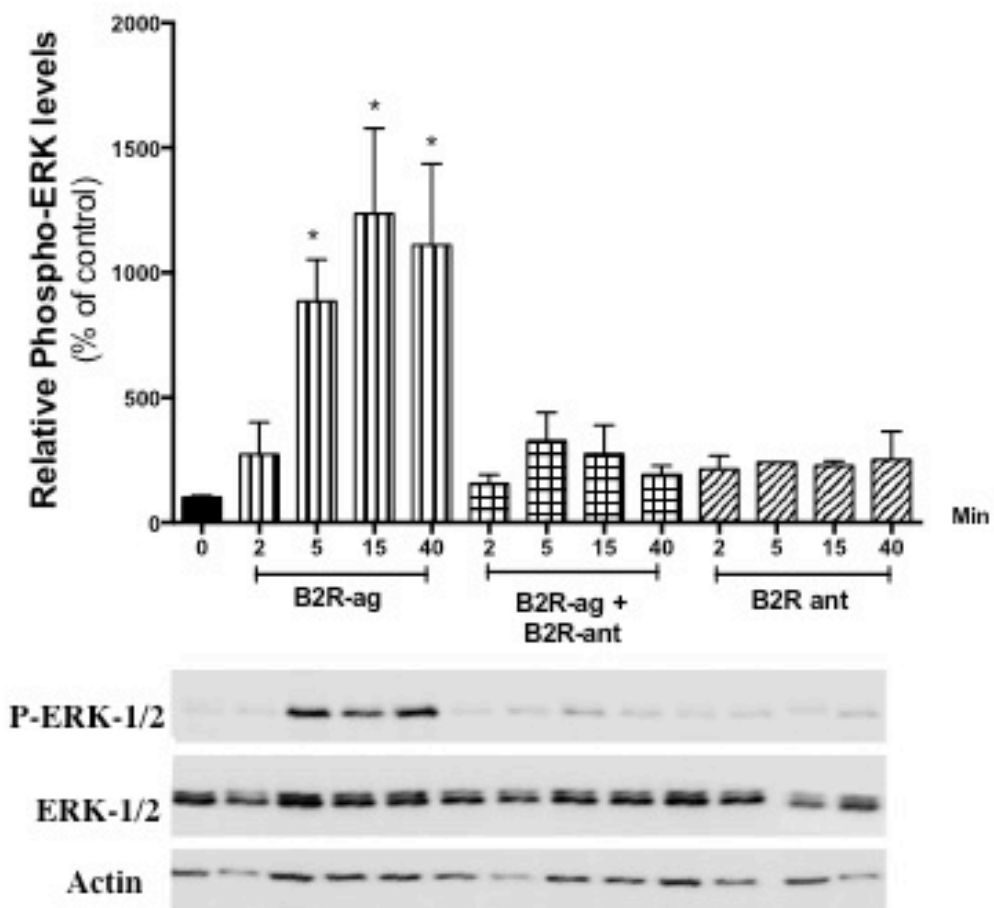